\title{
Patterns of Proteins Removed with High-Flux Membranes on High-Volume Hemodiafiltration Detected with a MultiDimensional LC-MS/MS Strategy
}

\author{
Luciano A. Pedrini $^{a} \quad$ Christoph Krisp ${ }^{b, c}$ Andreas Gmerek ${ }^{d} \quad$ Dirk A. Wolters $^{b}$

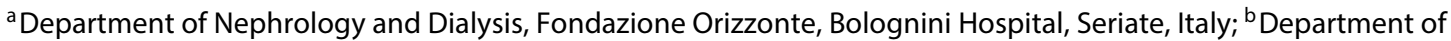 \\ Analytical Chemistry, Ruhr University Bochum, Bochum, Germany; ' Department of Chemistry and Biomolecular \\ Sciences, Macquarie University, Sydney, Australia; ${ }^{\mathrm{d} B}$. Braun Avitum AG, Melsungen, Germany
}

\section{Key Words}

Dialysis fluid · Hemodiafiltration - Membranes · Middle molecules $\cdot$ MudPIT $\cdot$ Permeability $\cdot$ Proteomics

\begin{abstract}
Background: Aim of this prospective crossover study was to identify the nature of the middle-molecular weight solutes removed during high-volume post-dilution HDF. Methods: The efficiency in removing small molecules, protein-bound and middle-molecular proteins was evaluated in 16 chronic dialysis patients on post-dilution HDF with two high-flux dialyzer membranes (Amembris and Polyamix). Multidimensional Protein Identification Technology (MudPIT) was employed to identify middle-molecular weight solutes in spent dialysate. Results: Efficiency of post-dilution HDF in removing solutes of different MW was high with both membranes, but higher with Amembris than with Polyamix. With MudPIT analysis, 277 proteins were identified in the dialysate fluids. Although the protein-removal pattern was similar among patients and tested membranes, the total and protein-specific peptide spectral count (mass spectrometric quantitation criteria) of most proteins were higher using the Amembris membrane. Conclusions: The MudPIT approach showed to be a powerful tool to identify a broad molecular weight
\end{abstract}

spectrum of proteins removed with post-dilution HDF. Short Summary: Aim of this prospective crossover study was to analyze the hydraulic properties of two high-flux dialyzer membranes (Amembris and Polyamix) during high-volume, post-dilution HDF and to evaluate the influence of these properties on the removal of proteins and peptides using an in-depth analysis of the spent dialysate. For this analysis, a liquid chromatography tandem mass spectrometry approach called MudPIT (Multidimensional Protein Identification Technology) was used to identify the middle molecular weight solutes present in the spent dialysate of patients. The capability of post-dilution HDF in removing solutes of different MW was very high with both dialyzers, but higher with the Amembris membrane. The proteomic MudPIT approach showed to be a powerful tool to identify a wide molecular spectrum of proteins removed from blood during post-dilution HDF. These results may contribute to address research toward a better knowledge of uremic toxins and the balance between the intended and unintended removal of undesired and beneficial proteins next to identification of new target proteins as potential candidates for uremic toxicity.

(c) 2014 S. Karger AG, Basel

Luciano A. Pedrini and Christoph Krisp contributed equally to this work.

\begin{tabular}{ll}
\hline KARGER & $\begin{array}{l}\text { ○ 2014 S. Karger AG, Basel } \\
\text { 0253-5068/14/0382-0115 } \$ 39.50 / 0 \quad \text { Karger }\end{array}$ \\
E-Mail karger@karger.com access \\
www.karger.com/bpu & $\begin{array}{l}\text { This is an Open Access article licensed under the terms of the } \\
\text { Creative Commons Attribution-NonCommercial 3.0 Un- } \\
\text { ported license (CC BY-NC) (www.karger.com/OA-license), } \\
\text { applicable to the online version of the article only. Distribu- } \\
\text { tion permitted for non-commercial purposes only. }\end{array}$
\end{tabular}

Luciano A. Pedrini

Department of Nephrology and Dialysis

Bolognini Hospital

IT-Seriate (Italy)

E-Mail axl.pedrini@virgilio.it 


\section{Introduction}

Findings of large, controlled trials have recently suggested that on-line hemodiafiltration (OL-HDF) with high volume exchange, compared with low-flux [1] and highflux hemodialysis (HD) [2,3] may significantly reduce the overall risk of death in patients on renal replacement therapy (RRT). High convective power techniques may enhance the removal of compounds of different molecular weights, which are known to be causative agents of severe uremic pathologies, such as cardiovascular disease, chronic inflammation, anemia, and bone metabolism derangement [4-8]. Reduced basal plasma levels of some of these compounds, such as $\beta 2$-microglobulin ( $\beta 2-\mathrm{m})$, phosphate $(\mathrm{P})$, and the protein-bound compounds $\mathrm{p}$-cresylsulphate and indoxylsulphate, have been associated with increased survival in uremic and dialysis patients [9-11]. However, accumulation of other known and unknown solutes may also contribute to uremic toxicity [12]. On the other hand, undesired removal by convection of some vital compounds could be detrimental to the patients well-being. Thus, a deeper knowledge of the molecular nature and biological and clinical effects of the compounds removed during convective high-efficiency therapies might help to shed light on their favorable clinical results.

A potentially applicable strategy to assess uremic toxin elimination efficiency is the multidimensional protein identification technology (MudPIT) [13]. This proteomic approach enables large-scale analysis of sequenced proteins by combining enzymatic protein digestion, 2D liquid chromatography (2D-LC), and tandem mass spectrometry (MS/MS). In addition to comparative investigation of uremic toxin elimination, the MudPIT approach might also identify novel uremic toxins.

In this prospective crossover study, hydraulic properties and the efficiency of two high-flux dialyzers in removing uremic solutes of different molecular weights were determined and the proteomic approach was applied to identify the nature of middle molecular solutes removed from blood and recovered in spent dialysis fluid during high-volume, post-dilution HDF.

\section{Subjects and Methods}

\section{Study Design}

This study was designed as a prospective, intra-individual, crossover comparison of two high-flux dialyzers, Xevonta Hi23 (Amembris, polysulfone membrane, B. Braun Avitum AG, Germany) and Polyflux ${ }^{\mathrm{TM}} 210 \mathrm{H}$ (Polyamix, polyamide membrane, Gambro, Italy) employed on post-dilution HDF. The main targets of the study were (1) the characterization of hydraulic properties of the membranes, (2) the comparative evaluation of small and middle molecular solute removal during post-dilution HDF, and (3) the in-depth determination of the nature of the removed compounds with a proteomic approach for analysis of the spent dialysate. The study was approved by the Ethic Committee of the Bolognini Hospital, Seriate, Italy, and was conducted in accordance with the principles of the Declaration of Helsinki and the rules of Good Clinical Practice.

\section{Patients}

Sixteen dialysis patients ( 13 male, 3 female), with mean age $61.8 \pm 11.5$, on stable thrice weekly RRT at the Nephrology and Dialysis Unit, Bolognini Hospital, Seriate, Italy, were included in the study after their informed consent. All patients had a permanent native or prosthetic vascular access capable of delivering an effective blood flow $\left(\mathrm{Q}_{\mathrm{B} \text { eff, nominal blood flow corrected for the effect }}\right.$ of the negative arterial pressure) of at least $300 \mathrm{ml} / \mathrm{min}$ without significant access recirculation $(<10 \%)$, monitored automatically and recorded every hour during the sessions with the 'Blood Temperature Monitoring' device integrated in the dialysis machine.

\section{Procedures}

After baseline assessments, the patients were randomized either to Amembris $(n=8)$ or Polyamix membrane $(n=8)$ and submitted for one week to post-dilution HDF. After a one-week washout period, patients were switched to the other dialyzer for another week. All study sessions were performed with a Fresenius 5008 machine (FMC, Bad Homburg, Germany) under the same operating conditions of $\mathrm{Q}_{B}$ eff, inlet dialysis fluid flow rate $\left(\mathrm{Q}_{\text {Din }}\right)$, duration, dialysate/infusate composition, and anticoagulation protocol. The highest ultrafiltration rate $\left(\mathrm{Q}_{\mathrm{UF}}\right)$ was applied under the control of a feedback system ensuring the maximum filtration pressure under safe operating conditions [14].

\section{Measurements and Calculations}

Blood samples drawn in the mid-week session from the arterial port before the treatment and at the end session with the slowflux technique were analyzed for urea $(\mathrm{U})$, phosphate $(\mathrm{P}), \beta 2-\mathrm{m}$, myoglobin (Myo), and total homocysteine (tHcy) using conductometric, colorimetric, and immunonephelometric methods, respectively. Effluent dialysate samples were also collected with a proportional pump at a constant rate of $10 \mathrm{ml} / \mathrm{h}$, following the partial dialysate quantification (DQ) method [15]. These samples, which were representative of the entire effective volume of spent dialysate $\left(\mathrm{V}_{\text {Dout }}\right)$, were analyzed for $\mathrm{U}, \mathrm{P}$, and albumin (immunonephelometry).

$\mathrm{V}_{\text {Dout }}(\mathrm{L})$ was quantified as the sum of the volume of the inlet dialysate (VDin, measured automatically and displayed by the machine), the volume of the substitution fluid (Vs) and the body weight loss (dBW):

$$
\mathrm{V}_{\text {Dout }}=\mathrm{V}_{\text {Din }}+\mathrm{Vs}+\mathrm{dBW}
$$

Mass transfer from the dialysate side $\left(\mathrm{MT}_{\mathrm{DQ}}\right)$ for $\mathrm{U}$ and $\mathrm{P}$ was calculated with the following equation:

$$
\mathrm{MT}_{\mathrm{DQ}}=\mathrm{Cd} \times \mathrm{V}_{\text {Dout }}
$$

where $\mathrm{Cd}(\mathrm{mg} / \mathrm{l})$ is the concentration of the examined solute in the effluent dialysate. 


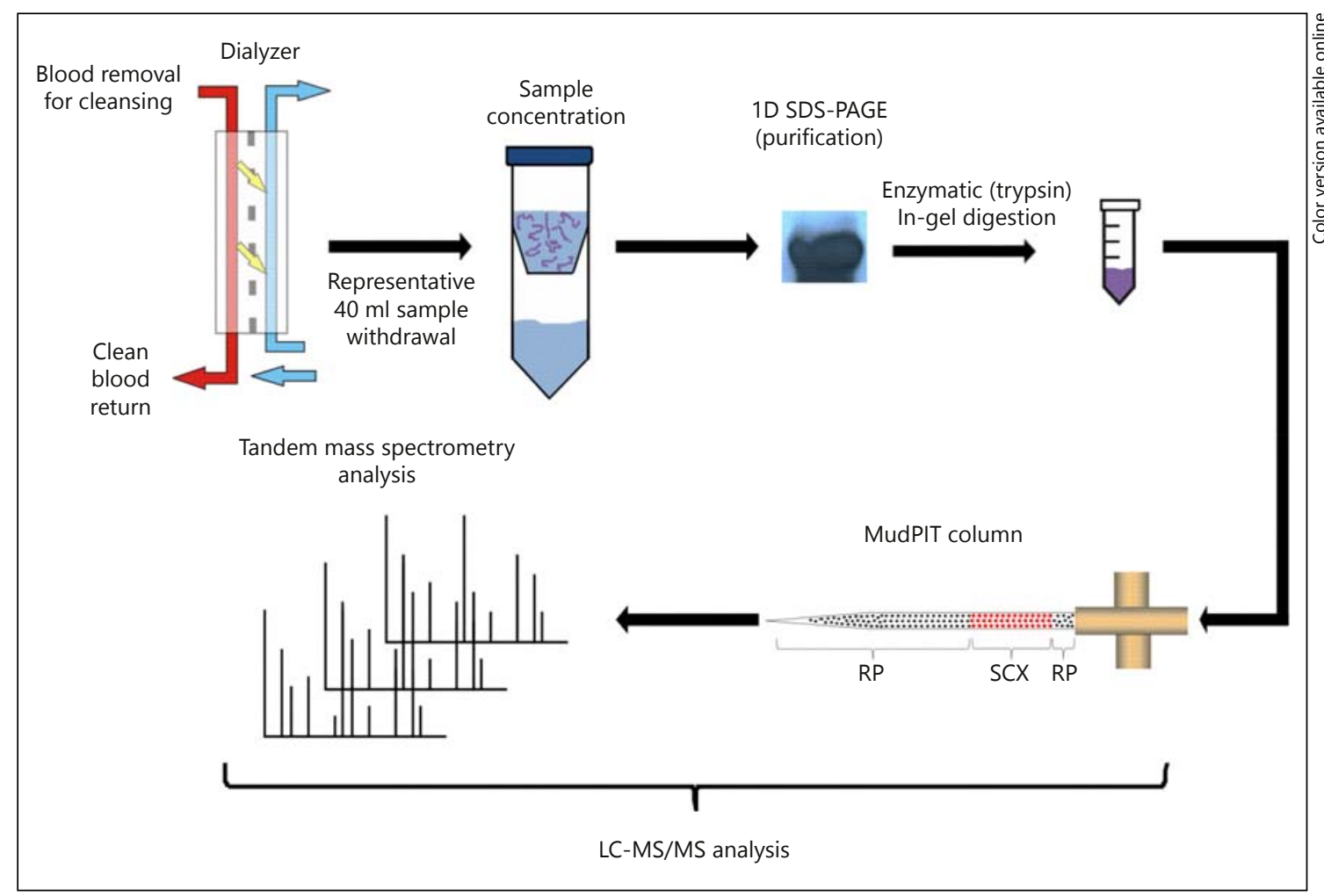

Fig. 1. MudPIT analysis workflow.

The mean dialysate clearances of the session $\left(\mathrm{K}_{\mathrm{DQ}}\right)$ for $\mathrm{U}$ and $\mathrm{P}$ were calculated with the following equation of the DQ method [15]:

$$
\mathrm{K}_{\mathrm{DQ}}=\left[\mathrm{MT}_{\mathrm{DQ}} \times \ln (\mathrm{Cf} / \mathrm{Ci})\right] /[\mathrm{t} \times(\mathrm{Cf}-\mathrm{Ci})]
$$

where $\mathrm{Ci}$ and $\mathrm{Cf}$ are the initial and end-session plasma water concentration of the examined solute and $t$ is the session duration in minutes. tion:

Urea equilibrated $\mathrm{Kt} / \mathrm{V}(\mathrm{eKt} / \mathrm{V})$ was calculated with the equa-

$$
\mathrm{eKt} / \mathrm{V}=\left(\mathrm{K}_{\mathrm{DQ}} \times \mathrm{t}\right) / \mathrm{V}_{\mathrm{U}}
$$

where $\mathrm{V}_{\mathrm{U}}$ is the Urea distribution volume estimated with the Watson equation.

Reduction Ratio (RR) for tHcy, $\beta 2-\mathrm{m}$ and Myo were calculated with the equation:

$$
\mathrm{RR}=(\mathrm{Ci}-\mathrm{Cf}) / \mathrm{Ci} \times 100
$$

Separate blood samples for tHcy, $\beta 2$-m and Myo were also drawn from the arterial and vein ports five minutes after the beginning and before the end of the session and used to calculate the instantaneous plasma water solute clearances $\left(\mathrm{K}_{\mathrm{PWinst}}, \mathrm{ml} / \mathrm{min}\right)$ with the classic equations [16], as an index of the dialyzer membrane permeability to protein-bound and middle molecular solutes:

$$
\mathrm{Q}_{\mathrm{PW}}(\text { plasma water flow rate })=\mathrm{Q}_{\mathrm{B} \text { eff }}(1-\mathrm{Hct} / 100) \mathrm{Fp}
$$

where Hct is Hematocrit and Fp is the water fraction of plasma;

$$
\mathrm{K}_{\mathrm{PWinst}}=\mathrm{Q}_{\mathrm{PW}}(\text { Cart }- \text { Cven }) / \text { Cart }+\mathrm{Q}_{\mathrm{UF}} \text { Cven/Cart }
$$

where Cart and Cven are the solute concentrations at the arterial and venous port respectively, and $Q_{U F}$ is the ultrafiltration rate $(\mathrm{ml} / \mathrm{min})$.

The pressure/flow conditions of the blood compartment were monitored by calculating the instantaneous values for the mean trans-membrane pressure (TMP, $\mathrm{mm} \mathrm{Hg}$ ), calculated as:

$$
\text { mean } \mathrm{TMP}=0.5 \times[(\mathrm{PB} \text { in }+\mathrm{PB} \text { out })-(\mathrm{PD} \text { in }+\mathrm{PD} \text { out })]-\mathrm{P}_{\text {onc }}
$$

where $\mathrm{PB}$ in, $\mathrm{PB}$ out, $\mathrm{PD}$ in, and $\mathrm{PD}$ out are the pressures ( $\mathrm{mm}$ $\mathrm{Hg}$ ) at the inlet and outlet blood and dialysate port, respectively; $\mathrm{P}_{\text {onc }}(\mathrm{mm} \mathrm{Hg})$, is the mean oncotic pressure exerted by the plasma proteins, set by default to a constant value of $25 \mathrm{~mm} \mathrm{Hg}$.

The in vivo ultrafiltration coefficients of the dialyzer membrane $\left(\mathrm{K}_{\mathrm{UF}}, \mathrm{ml} / \mathrm{h} / \mathrm{mm} \mathrm{Hg}\right.$ of $\left.\mathrm{TMP} / \mathrm{m}^{2}\right)$, were used as a proxy for changes in the hydraulic permeability of the dialyzers during the sessions.

\section{Sample Preparation (MudPIT)}

The multidimensional LC-MS/MS investigation workflow for spent dialysate samples is depicted in figure 1. A representative 40 $\mathrm{ml}$ dialysate sample for analysis with the MudPIT technology was collected from the first and second dialysis sessions of both study 
periods with the same partial DQ technique. Complete protease inhibitor cocktail tablets (Roche) were added to prevent the uncontrolled protein degradation. Dialysate fluids were concentrated by ultrafiltration using Amicon Ultra-15 centrifugal filter (Millipore) with a $3 \mathrm{kDa}$ molecular weight cut-off and ice-cold acetone precipitated. Protein concentrations were estimated by BCA assays (BCA Protein Assay Reagent kit, Pierce).

\section{SDS-PAGE}

Each sample was incubated in the presence of the reducing sample buffer ( $0.5 \mathrm{M}$ Tris-Hcl, pH 6.8, 3\% w/v SDS, 10\% v/v glycerol, $0.5 \% \mathrm{v} / \mathrm{v} 2$-mercaptoethanol, and bromophenol blue) for 10 min at $60^{\circ} \mathrm{C}$, then loaded onto $15 \%$ sodium dodecyl sulfate polyacrylamide gel electrophoresis (SDS-PAGE) gels, and run at a constant voltage of $100 \mathrm{~V}$. For sample purification, the run was stopped after the sample barely entered the running gel. Proteins were stained with Coomassie Brilliant Blue G-250 (Sigma-Aldrich).

\section{In-Gel Digestion and LC-MS/MS}

Coomassie-stained SDS-PAGE bands were cut into cubes and destained with $50 \% \mathrm{v} / \mathrm{v}$ acetonitrile $(\mathrm{ACN})$ and $25 \mathrm{mM} \mathrm{NH}_{4} \mathrm{HCO}_{3}$. Dried down gel cubes were moisturized with a trypsin solution (sequencing grade trypsin, Promega, dissolved in $25 \mathrm{mM} \mathrm{NH}_{4}$ $\mathrm{HCO}_{3}$ ) in an approximate protein/enzyme ratio of 50:1 and incubated overnight at $37^{\circ} \mathrm{C}$. Generated peptides were eluted from the gel with $50 \% \mathrm{v} / \mathrm{v} \mathrm{ACN}$ and $0.5 \% \mathrm{v} / \mathrm{v}$ trifluoroacetic acid. Peptides were offline loaded onto a MudPIT (see supplementary information for further explanation) fused silica column (inner diameter $=100 \mu \mathrm{m})$ consisting of $3 \mathrm{~cm}$ Luna C18 reversed phase (RP) material (Phenomenex) followed by $5 \mathrm{~cm}$ strong cation exchange (SCX) material (PolyLC) and a second $40 \mathrm{~cm}$ Luna C18 RP for the analytical separation of peptides at $45^{\circ} \mathrm{C}$. Peptides were eluted and transferred into an LTQ XL mass spectrometer (Thermo Fisher) by electrospray ionization (ESI) using an UltiMate HPLC (Dionex $\mathrm{GmbH}$ ). The effective flow rate in this setup was set to $130 \mathrm{nl} / \mathrm{min}$. Eleven successive ACN gradients containing salt steps of 10, 20, $30,40,50,60,80,100 \%$ of $250 \mathrm{~mm}$ ammonium acetate and $100 \%$ of $1.5 \mathrm{mM}$ ammonium acetate, were used for a stepwise elution of peptides from the MudPIT column, as described previously [17, 18].

Precursor ions were detected in a full MS scan form 400 to $2,000 \mathrm{~m} / \mathrm{z}$. Additionally, MS/MS experiments of the 10 most intense signals in the corresponding full MS scan were conducted.

Data Processing

Obtained MS/MS spectra were interpreted with the SEQUEST algorithm implemented in the Thermo Fisher Scientific Proteome Discoverer software (version 1.2). Spectra were searched against the human Swiss-Prot database (release 15.6/57.6). All accepted human peptides had false discovery rates (FDR) smaller than 0.05 , and a precursor mass accuracy of 2.5 Da. A tolerance of $1 \mathrm{Da}$ was used for fragment ions. Furthermore, all peptides had a probability score greater than 10 . Oxidation of methionine was set as a possible modification. Proteins with a minimum of 2 unique peptides were considered present in the sample. For comparative analyses, the number of annotated peptide spectra of each protein (SPCi) was normalized to the total spectrum count (SPCi/TSC; $\times 100)$ of each sample generating a percentage value.
Table 1. Patient and operational parameters

\begin{tabular}{|c|c|c|c|}
\hline Parameter & $\begin{array}{l}\text { Amembris } \\
\mathrm{n}=16\end{array}$ & $\begin{array}{l}\text { Polyamix } \\
\mathrm{n}=16\end{array}$ & p value* \\
\hline Dry body weight, kg & $77.6 \pm 11.0$ & $77.6 \pm 11.1$ & n.s. \\
\hline$\Delta \mathrm{BW}, \mathrm{kg}$ & $1.8 \pm 1.0$ & $2.3 \pm 0.8$ & $<0.005$ \\
\hline Treatment time, min & $227 \pm 14$ & $226 \pm 14$ & n.s. \\
\hline $\mathrm{Q}_{\mathrm{B} \text { eff }}, \mathrm{ml} / \mathrm{min}$ & $388 \pm 27$ & $388 \pm 26$ & n.s. \\
\hline $\mathrm{Q}_{\mathrm{UF}}, \mathrm{ml} / \mathrm{min}$ & $126 \pm 14$ & $116 \pm 10$ & $<0.001$ \\
\hline Volume exchange, $1 /$ session & $26.8 \pm 3.9$ & $24.0 \pm 3.3$ & $<0.001$ \\
\hline $\mathrm{Q}_{\text {Din }}, \mathrm{ml} / \mathrm{min}$ & $574 \pm 40$ & $575 \pm 40$ & n.s. \\
\hline \multicolumn{4}{|l|}{ Membrane } \\
\hline Surface, $\mathrm{m}^{2}$ & 2.3 & 2.1 & \\
\hline Wall thickness, $\mu \mathrm{m}$ & 35.0 & 30.0 & \\
\hline Inner diameter, $\mu \mathrm{m}$ & 195 & 200 & \\
\hline \multicolumn{4}{|l|}{ Nominal $\mathrm{K}_{\mathrm{UF}}, \mathrm{ml} / \mathrm{h} /$} \\
\hline $\mathrm{mm} \mathrm{Hg} / \mathrm{m}^{2}$ & 53.9 & 47.4 & \\
\hline
\end{tabular}

$\Delta \mathrm{BW}=$ Intra-dialytic weight loss; $\mathrm{Q}_{\mathrm{B} \text { eff }}=$ effective blood flow rate; $\mathrm{Q}_{\mathrm{UF}}=$ ultrafiltration rate; $\mathrm{Q}_{\mathrm{Din}}=$ inlet dialysate flow rate; $\mathrm{K}_{\mathrm{UF}}=$ ultrafiltration coefficient.

Data are means \pm SD

* Student's t test for paired data.

\section{Statistical Analysis}

The descriptive analysis was based on the mean \pm SD values of continuous normally distributed variables. The effects of the two procedures on the parameters of treatment and dialyzer efficiency $\left(\mathrm{K}_{\mathrm{I}}, \mathrm{K}_{\mathrm{DQ}}\right.$, urea $\mathrm{Kt} / \mathrm{V}$ and $\mathrm{MT}_{\mathrm{DQ}}$ ) were compared using the Student's $t$ test for paired data. A probability value of less than 0.05 was considered significant.

\section{Results}

\section{Removal Efficiency of the Dialyzers}

Patient and operational parameters of the sessions and concentration values of the studied solutes are reported in tables 1 and 2, respectively. The efficiency of post-dilution HDF in removing solutes of different MW was high with both membranes (table 3). Small solutes (U), the protein-bound tHcy and the middle molecular compounds $\beta 2-\mathrm{m}$ and Myo were more efficiently removed with the Amembris PS membrane, which showed greater hydraulic and solute permeability, as demonstrated by the trend of the in vivo ultrafiltration coefficients $\left(\mathrm{K}_{\mathrm{UF}}\right)$ of the two dialyzers during the sessions (fig. 2) and by calculation of solute $K_{\text {PWinst }}$ (table 3 ). A common tendency of both $K_{U F}$ and $K_{P W i n s t}$ to decrease toward the end of the sessions was shown due to the development and thickening of a secondary protein layer onto the membranes. As a result of these differences, the total exchange volume 
Table 2. Baseline and end-session patient parameters

\begin{tabular}{|c|c|c|c|c|}
\hline Parameter & & $\begin{array}{l}\text { Amembris } \\
(\mathrm{n}=16)\end{array}$ & $\begin{array}{l}\text { Polyamix } \\
(\mathrm{n}=16)\end{array}$ & p value* \\
\hline \multirow[t]{2}{*}{ Haematocrit, \% } & start & $36.2 \pm 2.6$ & $36.6 \pm 3.0$ & n.s. \\
\hline & end & $38.5 \pm 4.5$ & $39.3 \pm 4.3$ & n.s. \\
\hline \multirow[t]{2}{*}{ Total protein, g/dl } & start & $6.6 \pm 0.5$ & $6.6 \pm 0.5$ & n.s. \\
\hline & end & $7.0 \pm 0.7$ & $7.0 \pm 0.7$ & n.s. \\
\hline \multirow[t]{2}{*}{ Urea, mg/dl } & start & $132 \pm 20$ & $135 \pm 20$ & n.s. \\
\hline & end & $21 \pm 6$ & $23 \pm 7$ & $<0.005$ \\
\hline \multirow[t]{2}{*}{ Phosphate, mg/dl } & start & $4.6 \pm 1.1$ & $4.5 \pm 1.2$ & n.s. \\
\hline & end & $1.9 \pm 0.4$ & $1.9 \pm 0.5$ & n.s. \\
\hline \multirow[t]{3}{*}{ Total homocysteine, $\mu \mathrm{mol} / \mathrm{l}$} & start & $28.0 \pm 13.4$ & $26.9 \pm 11.5$ & n.s. \\
\hline & end & $11.6 \pm 5.5$ & $12.6 \pm 5.4$ & n.s. \\
\hline & corr. $\S$ & $10.3 \pm 4.8$ & $10.8 \pm 4.5$ & n.s. \\
\hline \multirow[t]{3}{*}{$\beta 2$-microglobulin, mg/l } & start & $24.5 \pm 3.9$ & $25.8 \pm 4.5$ & n.s. \\
\hline & end & $4.4 \pm 1.2$ & $6.8 \pm 1.7$ & $<0.0001$ \\
\hline & corr. $\S$ & $3.9 \pm 1.0$ & $5.9 \pm 1.5$ & $<0.0001$ \\
\hline \multirow[t]{3}{*}{ Myoglobin, ng/ml } & start & $201 \pm 83$ & $244 \pm 84$ & $<0.05$ \\
\hline & end & $75 \pm 33$ & $116 \pm 44$ & $<0.001$ \\
\hline & corr. $\S$ & $67 \pm 30$ & $100 \pm 37$ & $<0.005$ \\
\hline
\end{tabular}

Data are means \pm SD.

* Student's t test for paired data. ${ }^{\S}$ End-session value corrected for hemoconcentration.

Table 3. Efficiency of the sessions and dialyzers performance

\begin{tabular}{|c|c|c|c|c|c|}
\hline \multirow[t]{2}{*}{ Parameter } & \multirow{2}{*}{$\begin{array}{l}\text { Amembris } \\
(\mathrm{n}=16)\end{array}$} & \multirow{2}{*}{$\begin{array}{l}\text { Polyamix } \\
(\mathrm{n}=16)\end{array}$} & \multicolumn{3}{|l|}{$\mathrm{p}$ value* } \\
\hline & & & A vs. $P$ & $\begin{array}{l}\text { A, start } \\
\text { vs. end }\end{array}$ & $\begin{array}{l}P, \text { start } \\
\text { vs. end }\end{array}$ \\
\hline \multicolumn{6}{|l|}{ Urea } \\
\hline Mass transfer (DQ), g & $32.9 \pm 8.6$ & $32.5 \pm 10.9$ & n.s. & & \\
\hline $\mathrm{K}_{\mathrm{DQ}}, \mathrm{ml} / \mathrm{min}$ & $242.0 \pm 27.8$ & $222.5 \pm 36.7$ & $<0.01$ & & \\
\hline eKt/V (DQ) & $1.44 \pm 0.21$ & $1.31 \pm 0.21$ & $<0.005$ & & \\
\hline \multicolumn{6}{|l|}{ Phosphate } \\
\hline Mass transfer (DQ), mg & $1,058 \pm 222$ & $982 \pm 287$ & n.s. & & \\
\hline $\mathrm{K}_{\mathrm{DQ}}, \mathrm{ml} / \mathrm{min}$ & $158.1 \pm 30.6$ & $144.3 \pm 21.5$ & n.s. & & \\
\hline \multicolumn{6}{|l|}{ Total homocysteine } \\
\hline Reduction ratio, \% & $62.8 \pm 5.6$ & $59.6 \pm 5.9$ & $<0.05$ & & \\
\hline $\mathrm{K}_{\text {PWinst }}$ start session, $\mathrm{ml} / \mathrm{min}$ & $88.7 \pm 15.8$ & $75.4 \pm 14.0$ & $<0.05$ & $<0.001$ & $<0.001$ \\
\hline $\mathrm{K}_{\text {PWinst }}$ end session, $\mathrm{ml} / \mathrm{min}$ & $33.9 \pm 10.6$ & $30.1 \pm 12.3$ & n.s. & & \\
\hline \multicolumn{6}{|l|}{$\beta 2$-microglobulin } \\
\hline Reduction ratio, $\%$ & $83.9 \pm 3.7$ & $77.2 \pm 3.8$ & $<0.001$ & & \\
\hline $\mathrm{K}_{\text {PWinst }}$ start session, $\mathrm{ml} / \mathrm{min}$ & $148.3 \pm 9.3$ & $126.2 \pm 19.1$ & $<0.001$ & $<0.001$ & $<0.001$ \\
\hline $\mathrm{K}_{\mathrm{PW} \text { inst }}$ end session, $\mathrm{ml} / \mathrm{min}$ & $109.9 \pm 18.0$ & $83.8 \pm 23.7$ & $<0.005$ & & \\
\hline \multicolumn{6}{|l|}{ Myoglobin } \\
\hline Reduction ratio, \% & $66.4 \pm 7.4$ & $58.8 \pm 7.1$ & $<0.001$ & & \\
\hline $\mathrm{K}_{\text {PWinst }}$ start session, $\mathrm{ml} / \mathrm{min}$ & $116.8 \pm 12.0$ & $91.5 \pm 21.1$ & $<0.001$ & $<0.001$ & $<0.001$ \\
\hline $\mathrm{K}_{\text {PWinst }}$ end session, $\mathrm{ml} / \mathrm{min}$ & $58.2 \pm 15.7$ & $44.3 \pm 14.9$ & $<0.05$ & & \\
\hline
\end{tabular}

Means \pm SD of all patients. Data are means \pm SD.

$\mathrm{K}_{\mathrm{DQ}}=$ Mean clearance of the session from the dialysate quantification; $\mathrm{K}_{\mathrm{PWinst}}=$ instantaneous plasma water clearance; $\mathrm{A}=$ Amembris membrane; $\mathrm{P}=$ Polyamix membrane.

* Student's t test for paired data. 
Fig. 2. Mean trend of the apparent ultrafiltration coefficient $\left(\mathrm{K}_{\mathrm{UF}}\right)$ of the two compared membranes during the experimental HDF sessions. Upper line (A), Amembris membrane; lower line $(\mathrm{P})$, Polyamix membrane.

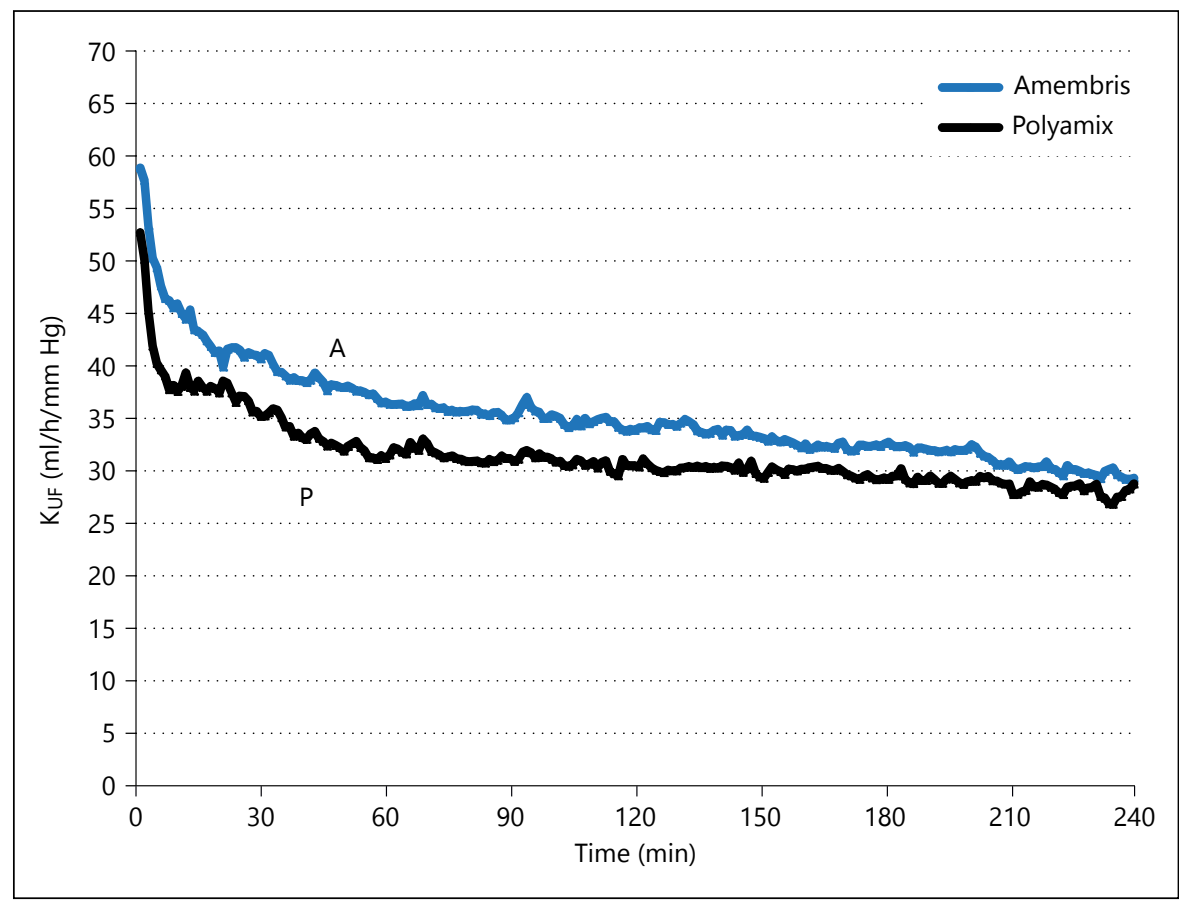

obtained by applying similar filtration pressure was very high in both compared treatments and higher with the PS-membrane (table 1).

Albumin leakage was quite negligible from the clinical point of view with both membranes, but it was statistically lower with Polyamix versus Amembris (824 \pm 772 vs. $2,018 \pm 1,863 \mathrm{mg} / \mathrm{session}$, respectively, $\mathrm{p}=$ $0.003)$.

\section{Multidimensional LC-MS/MS Analysis of Protein Elimination}

MudPIT analysis of spent dialysate was applied to 9 out of 16 randomly selected patients, twice per patient per dialyzer, for a total of 36 treatment sessions. The mean efficiency parameters of these sessions are reported in table 4. Treatment sequence was Amembris/Polyamix (A/P) for 5 patients and Polyamix/Amembris (P/A) for 4 patients.

For each of the 9 patients, the prevalent proteins were identified with this proteomic approach. Patient-specific profiles of proteins in a mass range from 5 to $80 \mathrm{kDa}$ removed by the employed dialyzers were assessed by the differences of the Total Spectral Count (TSC) percentages of identified proteins (data not shown). Overall, a total of 277 proteins in a wide range of molecular weights were identified by their unique peptide sequence. Both tested membranes are supposed to have a well-defined cut-off allowing the efficient removal of middle molecules but preventing excessive loss of serum albumin. Nonetheless, proteins with molecular masses higher than $69 \mathrm{kDa}$ were identified in spent dialysis fluid of both membranes. Proteins above $80 \mathrm{kDa}$ made up $5.9 \%$ of the TSC. Several proteins undergo further proteolytic processing after secretion. Proteins can be identified by mass spectrometry by their unique sequence of peptides. Thus, the identification of proteolysis products instead of the protein precursor itself was observed in our study for some high molecular weight proteins, such as collagens, and in all patients, the basement membrane-specific heparin sulfate proteoglycan core protein (perlecan). Metabolism of this $468 \mathrm{kDa}$ protein is a typical example in that it is enzymatically processed at the C-terminus to produce endorepellin $(75.9 \mathrm{kDa})$, which can be further degraded to the LG3 peptide ( $25 \mathrm{kDa}$ ) [19]. Theoretically, due to the large size of the protein, tryptic peptides from the entire protein should be detected, if filters were not working properly. In fact, only perlecan peptides from the C-terminal LG3 peptide region were identified in the dialysate fluids.

The sum of the identified peptide spectra per protein showed that the Amembris membrane, compared to the Polyamix membrane, has a greater capacity to remove proteins in the overall range of tested molecular weights (fig. 3a, b), as well as in specific categorized molecular 


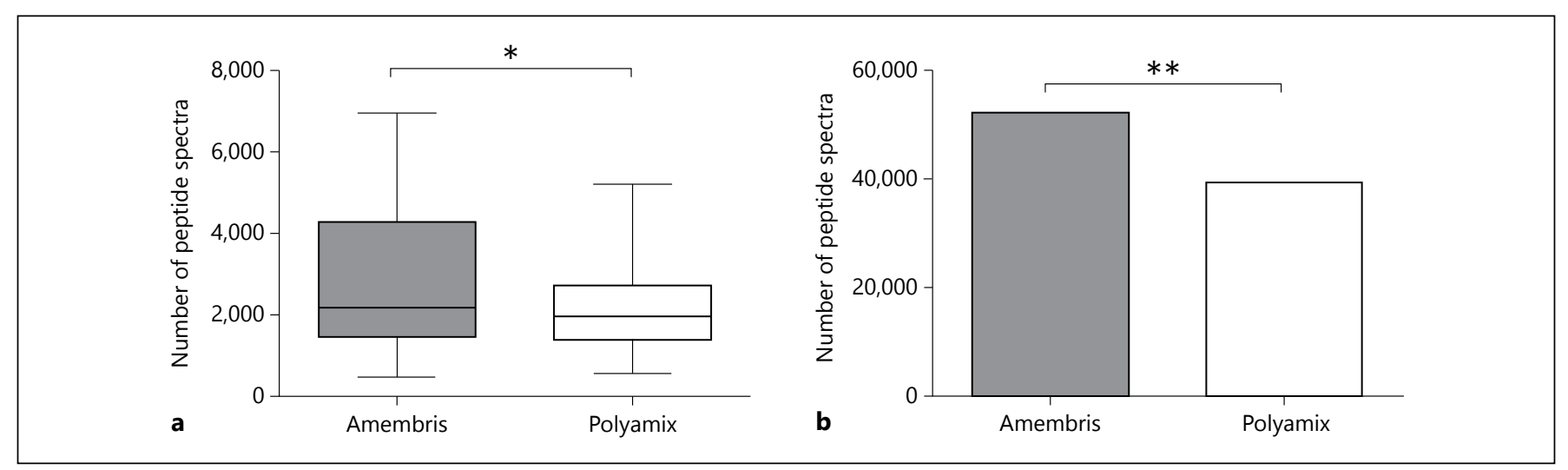

Fig. 3. a Mean number of peptide spectra per patient and filter. b Sum of the total peptide spectra in all patients. Student's $t$ test, * $\mathrm{p}<$ $0.05,{ }^{* *} \mathrm{p}<0.01$.

Table 4. Efficiency of the sessions and dialyzers performance in patients analyzed with MudPIT procedure $(\mathrm{n}=9)$

\begin{tabular}{|c|c|c|c|c|c|}
\hline \multirow[t]{2}{*}{ Parameter } & \multirow[t]{2}{*}{ Amembris } & \multirow[t]{2}{*}{ Polyamix } & \multicolumn{3}{|l|}{$\mathrm{p}$ value* } \\
\hline & & & A vs. $P$ & $\begin{array}{l}\text { A, start } \\
\text { vs. end }\end{array}$ & $\begin{array}{l}\mathrm{P} \text {, start } \\
\text { vs. end }\end{array}$ \\
\hline \multicolumn{6}{|l|}{ Urea } \\
\hline $\mathrm{K}_{\mathrm{DQ}}, \mathrm{ml} / \mathrm{min}$ & $248.5 \pm 28.9$ & $223.8 \pm 45.4$ & $<0.05$ & & \\
\hline eKt/V (DQ) & $1.42 \pm 0.16$ & $1.27 \pm 0.2$ & $<0.05$ & & \\
\hline \multicolumn{6}{|l|}{ Phosphate } \\
\hline $\mathrm{K}_{\mathrm{DQ}}, \mathrm{ml} / \mathrm{min}$ & $165.3 \pm 34.6$ & $144.5 \pm 22.3$ & n.s. & & \\
\hline \multicolumn{6}{|l|}{ Total homocysteine } \\
\hline $\mathrm{RR}, \%$ & $61.0 \pm 5.1$ & $58.9 \pm 6.1$ & n.s. & & \\
\hline $\mathrm{K}_{\text {PWinst }}$ start session, $\mathrm{ml} / \mathrm{min}$ & $86.4 \pm 18.0$ & $71.9 \pm 14.8$ & n.s. & $<0.001$ & $<0.001$ \\
\hline $\mathrm{K}_{\text {PWinst }}$ end session, $\mathrm{ml} / \mathrm{min}$ & $33.6 \pm 12.7$ & $24.5 \pm 10.7$ & n.s. & & \\
\hline \multicolumn{6}{|l|}{$\beta 2$-microglobulin } \\
\hline $\mathrm{RR}, \%$ & $82.7 \pm 3.2$ & $76.7 \pm 3.8$ & $<0.001$ & & \\
\hline $\mathrm{K}_{\mathrm{PWinst}}$ start session, $\mathrm{ml} / \mathrm{min}$ & $146.1 \pm 7.8$ & $117.4 \pm 15.8$ & $<0.001$ & $<0.001$ & $<0.001$ \\
\hline $\mathrm{K}_{\text {PWinst }}$ end session, $\mathrm{ml} / \mathrm{min}$ & $117.2 \pm 13.2$ & $81.0 \pm 22.4$ & $<0.001$ & & \\
\hline \multicolumn{6}{|l|}{ Myoglobin } \\
\hline R R, \% & $62.7 \pm 7.5$ & $54.8 \pm 3.6$ & $<0.01$ & & \\
\hline $\mathrm{K}_{\text {PWinst }}$ start session, $\mathrm{ml} / \mathrm{min}$ & $110.3 \pm 9.4$ & $89.0 \pm 24.9$ & $<0.05$ & $<0.001$ & $<0.001$ \\
\hline $\mathrm{K}_{\mathrm{PWinst}}$ end session, $\mathrm{ml} / \mathrm{min}$ & $57.5 \pm 16.1$ & $40.7 \pm 17.1$ & n.s. & & \\
\hline
\end{tabular}

Data are means \pm SD.

$\mathrm{K}_{\mathrm{DQ}}=$ Mean clearance from the dialysate; $\mathrm{RR}=$ reduction ratio; $\mathrm{K}_{\mathrm{PWinst}}=$ instantaneous plasma water clearance.

* Student's t test for paired data.

mass ranges (fig. 4). Statistically significant differences were found in the molecular weight ranges from 10 to 40 $\mathrm{kDa}$ and 50 to $60 \mathrm{kDa}$. Proteins recovered in the spent dialysate were plotted by their molecular weights against the sum of the mean peptide spectra per protein identified within the patient cohort of tested membrane. It may be observed that protein-removal patterns were similar be- tween patients and membranes in both mean (fig. 5a) and individual data (not shown), but the differential plot, which subtracts the number of peptide spectra of the Amembris from the Polyamix membrane, displays very well that the amount of the most removed proteins was generally higher with the Amembris membrane (fig. 5b). Table 5 lists the 50 most common proteins and their in- 
Fig. 4. Column diagram of the total spectrum count of molecular weight clustered proteins. * Student's t test, $\mathrm{p}<0.05$.
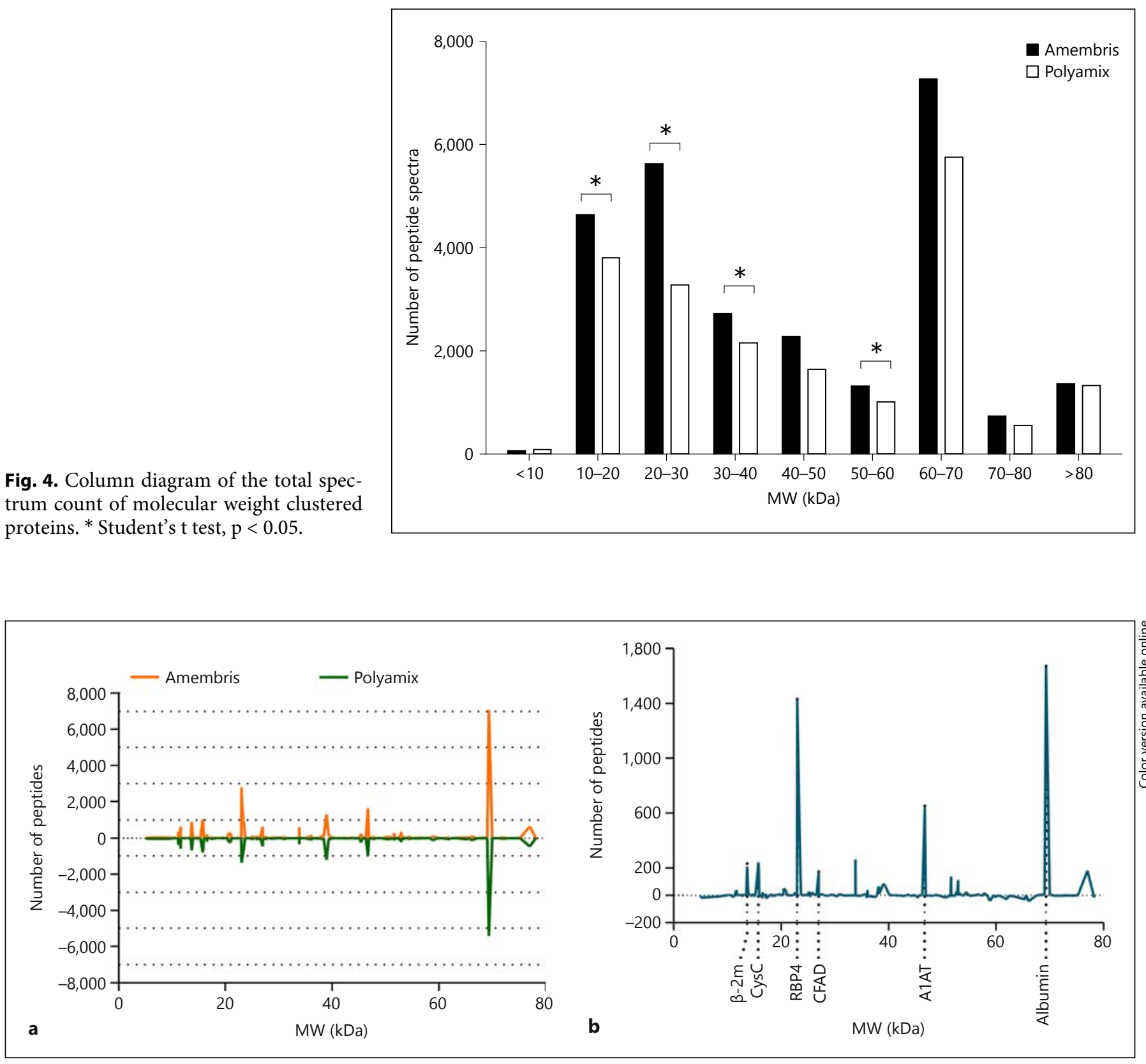

Fig. 5. a The upper part of the graph (over the $\mathrm{x}$ axis) depicts the number of peptide counts for Amembris plotted by the molecular weight, the lower part the number of peptide counts for Polyamix.

dividual mean peptide spectral count that were identified in the dataset of the 9 patients.

Serum albumin was the protein with the highest removal rate in each patient, independent from the dialyzer membrane. Its patient-specific spectral count in relation to TSC varied from 15 up to $40 \%$. However, TSCs for albumin for both membranes were not significantly different. b Differential molecular weight profile plot of the two filters (Amembris-Polyamix). Major peaks of toxins, A1AT, and albumin are annotated.

\section{Discussion}

As suggested by the most recent trials (ESHOL, CONTRAST and Turkish HDF Studies), high convective volumes on HDF may play an important role to obtain significant benefit in terms of survival of patients on RRT. Besides other patient and operational parameters 
Table 5. List of the most common proteins recovered in spent dialysis fluid with MudPIT

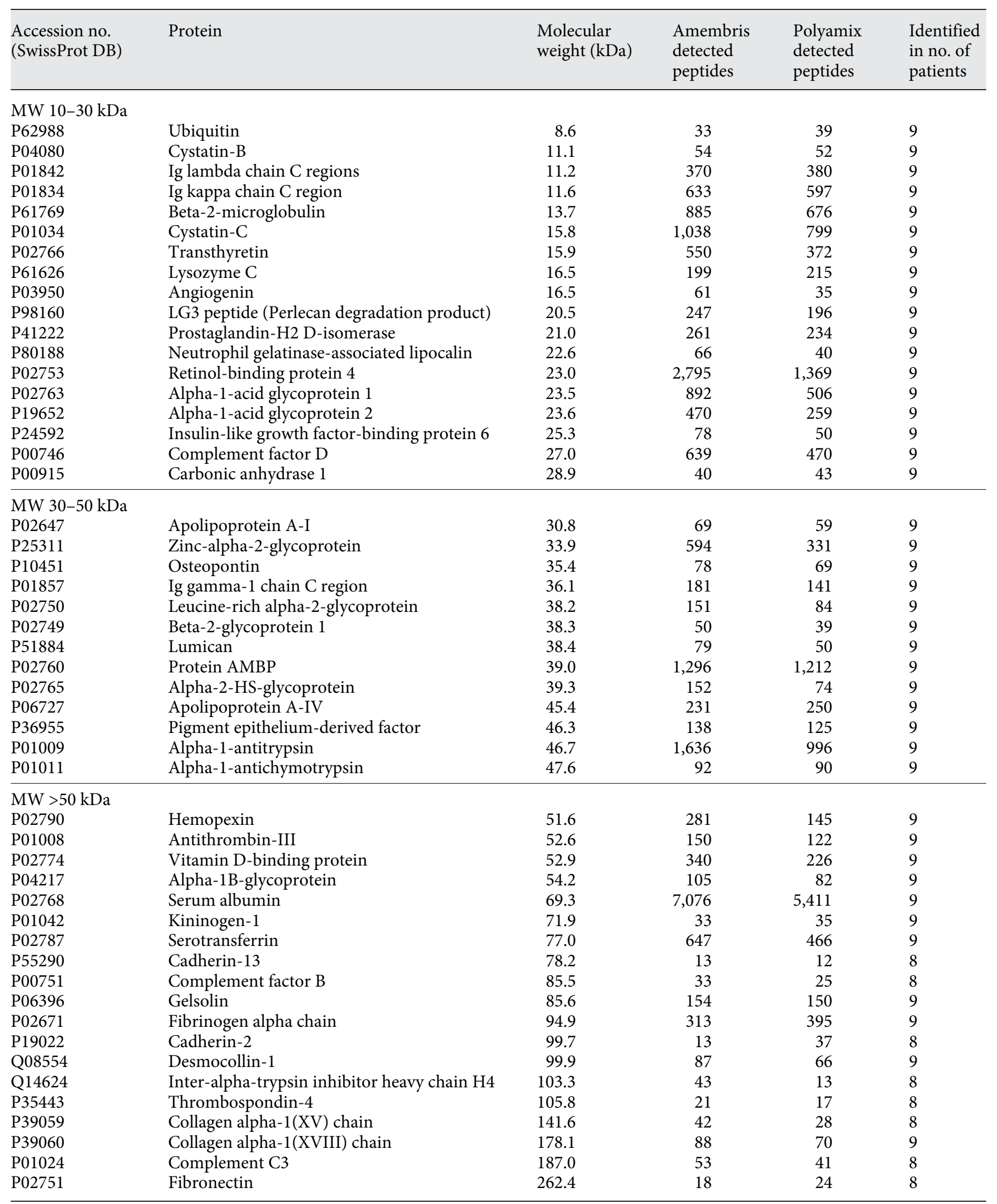


(blood flow, treatment time and frequency, etc.), the convective power of high-flux membranes is a fundamental component required to achieve this goal. The optimalperforming membrane should eliminate accumulated proteins with putative toxic potential, while leaving essential macromolecules undepleted.

The performance of high-flux membranes depends on several factors, such as its chemical composition and surface area, but it is predominantly determined by the size, distribution, and quantity of pores. While pore size is the most important factor for defining the cut-off of a membrane, the quantity of pores and pore size distribution determine its permeability to fluids and solutes, besides the hydrophobic and hydrophilic areas resulting from the chemical composition of the membrane.

In this study, high-efficiency HDF was performed with polysulfone and polyamide high-flux membranes, but higher volume exchange was possible with the former membrane as an effect of its greater hydraulic permeability. As a result, marker solutes for middle molecules ( $\beta 2$ $\mathrm{m}$, myoglobin) were more efficiently removed during the HDF sessions in which this membrane was employed. The enhanced removal effect of this membrane was also shown on free (urea) and protein-bound (total homocysteine) small solutes. Transfer of these molecules mainly occurs by diffusion, but it is widely accepted that an additional effect may be also exerted by convection during HDF $[7,8]$. Phosphate removal, even remarkably high during all sessions, was not significantly different between the two tested membranes.

In addition to the removal efficiency study, we applied a multidimensional LC-MS/MS approach using labelfree spectral counting as a relative quantitation technique to identify the amount and type of proteins removed with the two tested membranes and recovered in the spent dialysate. In general, protein concentration patterns in spent dialysis fluids should be similar to that of plasma, which has been described by Anderson et al. [20], up to the specific cut-off of the employed membrane, with the limitation posed by the adsorption onto the inner membrane surface of some compounds according to their electro-chemical interactions with the membrane itself.

Mass spectrometric analyses identified a number of protein compounds whose removal pattern was similar in all tested dialysate fluids, irrespective of the patients and the employed membranes. TSC of the protein recovered in the spent dialysate (fig. 5) of the HDF sessions performed with the Xevonta dialyzer were generally higher when compared to those of the Polyflux dialyzer, confirming the greater solute permeability of the former membrane.
Ficheux et al. [21] investigated in a comparative study the removal efficiencies of Xevonta Hi23, Xenium 210 and FX 100 dialyzers with an SDS-PAGE scanning method. They described similar observations of removal efficiencies of Xevonta membranes for middle molecular proteins and identified the optimum of protein elimination in the mass range from 20 to $30 \mathrm{kDa}$, which is coherent with the findings of our study. According to figure 4, the relative difference of the spectral counts in favor to the Amembris membrane is most striking in this mentioned 20-30 kDa range.

Besides the results of the comparison, this investigation added some information about the efficiency of high-flux membranes to remove compounds in the whole range of molecular weight up to the membrane cut-off and above, thanks to the ability of the MudPIT technology to identify proteins by their unique sequence of peptides even after the degradation of the intact compound. Inspection of the most abundant proteins identified in the dialysate (table 5) suggests that convective solute removal during HDF may modify the uremic plasma composition by abating the level of some toxic substances but, possibly, also by depleting useful compounds of lower molecular weight. The list includes a number of compounds whose metabolic role and effects of accumulation in uremic plasma are known, such as $\beta 2-\mathrm{m}$, CysC, myoglobin, complement factor $\mathrm{D}$, and RBP4 [22], proteins which are of high concentration in human plasma. Some of them have function in transport processes, as serum albumin or serotransferrin, others are involved in immune response and regulation, as different immunoglobulin isoforms, or proteins could be found in coagulation processes. Proteins, whose effects have been less described, have been identified in comparable abundance to $\mathrm{RBP} 4$ and CysC. This is the case for the protein AMBP (alpha-1 microglobulin/bikunin precursor). Protein AMBP can be cleaved into the 3 chains: alpha-1-microglobulin, inter-alpha-trypsin inhibitor light chain, and trypstatin. Alpha-1-microglobulin is a marker for renal abnormalities and mentioned in the EUTox database. It displays elevated protein levels in serum/plasma or urine as reviewed in several publications [23-25]. The spectral counts displayed 1,296 peptides in the dialysates using the Amembris membrane in contrast to the 1,212 peptides using the Polyamix membrane (table 5). This is a small advantage of the Amembris membrane given by the pure numbers. In fact, both membranes show equally high numbers and feature excellent performance. Also Prostaglandin D2 synthase (PTGDS) showed high spectral counts. PTGDS is supposed to stimulate apoptosis in 
pig kidney [26] and to contribute to progression of renal failure and dialysis dementia [27]. On the other hand, Vitamin D-binding protein (VDBP), one of the major vitamin D-transporting proteins in blood, showed high spectral counts in both datasets of the membranes tested in this study. High removal of VDBP may lead to lack of vitamin $\mathrm{D}$, and therefore an unwanted condition in dialysis patients [28].

It is beyond the aim of this study to describe the metabolic role and the effects of the accumulation/depletion in plasma of all proteins recovered in the spent dialysis fluid of the experimental HDF sessions of the study. However, these results might contribute to address research toward a better knowledge of some uremic toxins and to identify new target proteins as potential candidates for uremic toxicity. The combination of clinical parameters and mass spectrometric tools may help to investigate in a comprehensive approach the effect of the physical characteristics of high-flux membranes and to improve their selective permeability to solutes of the desired molecular range.

\section{Conclusions}

Both Amembris and Polyamix high-flux membranes when tested on post-dilution HDF showed remarkable efficiency and safety in removing small, medium-sized and protein-bound solutes, thanks to their high hydraulic and solute permeability, which ensured an amount of convective volume well above that level which may grant substantial survival benefit to HDF patients according to the results of the most recent large trials.

The MudPIT approach showed to be a powerful tool to identify a wide molecular spectrum of proteins removed from blood during post-dilution HDF and recovered in spent dialysate of post-HDF, which were removed from blood to a greater extent with the Amembris membrane than with the Polyamix membrane. Some of these proteins might be responsible, at least partially, for the clinical manifestation of the uremic syndrome. Some others could be recognized as new potential uremic toxins. Their identification through the MudPIT analysis could provide new tools to understand the benefits of the convective techniques on survival of uremic patients.

\section{Acknowledgments}

We like to thank Benjamin Fränzel for critically proofreading and fruitful discussion of the manuscript, and all dialysis patients who participated in this study. The authors also thank the nursing staff for their continuing assistance in the management of the patients.

\section{Disclosure Statements}

This project was financially supported by B. Braun Avitum AG, Melsungen, Germany. A. Gmerek is an employee of B. Braun Avitum AG. The authors LAP CK, MT, and DW disclose no conflict of interest in this work.

Part of this work has been presented at the 2011 Annual Meeting of the ERA-EDTA in Prague, Czech Republic.

\section{References}

$>1$ Grooteman MP, van den Dorpel MA, Bots ML, Penne EL, van der Weerd NC, Mazairac $\mathrm{AH}$, den Hoedt $\mathrm{CH}$, van der Tweel I, Levesque R, Nube MJ, ter Wee PM, Blankestijn PJ: Effect of online hemodiafiltration on all-cause mortality and cardiovascular outcomes. J Am Soc Nephrol 2012;23:1087-1096.

$>2$ Ok E, Asci G, Toz H, Ok ES, Kircelli F, Yilmaz M, Hur E, Demirci MS, Demirci C, Duman S, Basci A, Adam SM, Isik IO, Zengin M, Suleymanlar G, Yilmaz ME, Ozkahya M: Mortality and cardiovascular events in online haemodiafiltration (OL-HDF) compared with highflux dialysis: results from the Turkish OLHDF Study. Nephrol Dial Transplant 2013; 28:192-202.

-3 Maduell F, Moreso F, Pons M, Ramos R, Mora-Macia J, Carreras J, Soler J, Torres F, Campistol JM, Martinez-Castelao A: High-efficiency postdilution online hemodiafiltration re- duces all-cause mortality in hemodialysis patients. J Am Soc Nephrol 2013;24:487-497.

$\checkmark 4$ Bonomini M, Ballone E, Di Stante S, Bucciarelli T, Dottori S, Arduini A, Urbani A, Sirolli V: Removal of uraemic plasma factor(s) using different dialysis modalities reduces phosphatidylserine exposure in red blood cells. Nephrol Dial Transplant 2004;19:6874.

5 Carracedo J, Merino A, Nogueras S, Carretero D, Berdud I, Ramirez R, Tetta C, Rodriguez M, Martin-Malo A, Aljama P: On-line hemodiafiltration reduces the proinflammatory CD14+CD16+ monocyte-derived dendritic cells: a prospective, crossover study. J Am Soc Nephrol 2006;17:2315-2321.

6 Kuo HL, Chou CY, Liu YL, Yang YF, Huang $\mathrm{CC}$, Lin HH: Reduction of pro-inflammatory cytokines through hemodiafiltration. Ren Fail 2008;30:796-800.
7 Meert N, Eloot S, Waterloos MA, Van Landschoot M, Dhondt A, Glorieux G, Ledebo I, Vanholder R: Effective removal of proteinbound uraemic solutes by different convective strategies: a prospective trial. Nephrol Dial Transplant 2009;24:562-570.

$>8$ Pedrini LA, De Cristofaro V, Comelli M, Casino FG, Prencipe M, Baroni A, Campolo G, Manzoni C, Coli L, Ruggiero P, Acquistapace I, Auriemma L: Long-term effects of high-efficiency on-line haemodiafiltration on uraemic toxicity. A multicentre prospective randomized study. Nephrol Dial Transplant 2011;26:2617-2624.

$\checkmark 9$ Cheung AK, Rocco MV, Yan G, Leypoldt JK, Levin NW, Greene T, Agodoa L, Bailey J, Beck GJ, Clark W, Levey AS, Ornt DB, Schulman G, Schwab S, Teehan B, Eknoyan G: Serum beta-2 microglobulin levels predict mortality in dialysis patients: results of the HEMO study. J Am Soc Nephrol 2006;17:546-555. 
10 Covic A, Kothawala P, Bernal M, Robbins S, Chalian A, Goldsmith D: Systematic review of the evidence underlying the association between mineral metabolism disturbances and risk of all-cause mortality, cardiovascular mortality and cardiovascular events in chronic kidney disease. Nephrol Dial Transplant 2009;24:1506-1523.

11 Liabeuf S, Barreto DV, Barreto FC, Meert N, Glorieux G, Schepers E, Temmar M, Choukroun G, Vanholder R, Massy ZA: Free p-cresylsulphate is a predictor of mortality in patients at different stages of chronic kidney disease. Nephrol Dial Transplant 2010;25:1183-1191.

12 Vanholder R, De Smet R, Glorieux G, Argiles A, Baurmeister U, Brunet P, Clark W, Cohen G, De Deyn PP, Deppisch R, Descamps-Latscha B, Henle T, Jorres A, Lemke HD, Massy ZA, Passlick-Deetjen J, Rodriguez M, Stegmayr B, Stenvinkel P, Tetta C, Wanner C, Zidek W: Review on uremic toxins: classification, concentration, and interindividual variability. Kidney Int 2003;63:1934-1943.

-13 Mann H, Melzer H, Al-Bashir A, Xu XQ, Stiller S: Testing protein permeability of dialysis membranes using SDS-PAGE. Int J Artif Organs 2002;25:441-446.

-14 Pedrini LA, Cozzi G, Faranna P, Mercieri A, Ruggiero P, Zerbi S, Feliciani A, Riva A: Transmembrane pressure modulation in high-volume mixed hemodiafiltration to optimize efficiency and minimize protein loss. Kidney Int 2006;69:573-579.
15 Depner TA, Keshaviah PR, Ebben JP, Emerson PF, Collins AJ, Jindal KK, Nissenson AR, Lazarus JM, Pu K: Multicenter clinical validation of an on-line monitor of dialysis adequacy. J Am Soc Nephrol 1996;7:464-471.

16 Sargent JA, Gotch FA: Principles and Biophysics of Dialysis; in Jacobs C, Kjellstrand CM, Koch KM, Winchester JF (eds): Replacement of Renal Function by Dialysis. Dordrecht, Kluwer Academic 1996, pp 34-102.

17 Washburn MP, Wolters D, Yates JR III: Large-scale analysis of the yeast proteome by multidimensional protein identification technology. Nat Biotechnol 2001;19:242-247.

18 Wolters DA, Washburn MP, Yates JR III: An automated multidimensional protein identification technology for shotgun proteomics. Anal Chem 2001;73:5683-5690.

19 Oda O, Shinzato T, Ohbayashi K, Takai I, Kunimatsu M, Maeda K, Yamanaka N: Purification and characterization of perlecan fragment in urine of end-stage renal failure patients. Clin Chim Acta 1996;255:119-132.

20 Anderson NL, Anderson NG: The human plasma proteome: history, character, and diagnostic prospects. Mol Cell Proteomics 2002;1:845-867.

21 Ficheux A, Gayrard N, Szwarc I, Andress D, Soullier S, Duny Y, Goubert G, Thomas M, Bismuth-Mondolfo J, Daures JP, Brunet P, Servel MF, Argiles A: The use of SDS-PAGE scanning of spent dialysate to assess uraemic toxin removal by dialysis. Nephrol Dial Transplant 2011;26:2281-2289.
22 Eutox-Database: http://www.nephro-leipzig. de/eutoxdb/index.php, 2013.

23 Cruz DN, de Geus HR, Bagshaw SM: Biomarker strategies to predict need for renal replacement therapy in acute kidney injury. Semin Dial 2011;24:124-131.

24 Penders J, Delanghe JR: Alpha 1-microglobulin: clinical laboratory aspects and applications. Clin Chim Acta 2004;346:107-118.

25 Pio R, Martinez A, Unsworth EJ, Kowalak JA, Bengoechea JA, Zipfel PF, Elsasser TH, Cuttitta F: Complement factor $\mathrm{H}$ is a serum-binding protein for adrenomedullin, and the resulting complex modulates the bioactivities of both partners. J Biol Chem 2001;276:1229212300.

26 Maesaka JK, Palaia T, Frese L, Fishbane S, Ragolia L: Prostaglandin $\mathrm{D}(2)$ synthase induces apoptosis in pig kidney LLC-PK1 cells. Kidney Int 2001;60:1692-1698.

27 Maesaka JK, Palaia T, Fishbane S, Ragolia L: Contribution of prostaglandin D2 synthase to progression of renal failure and $\mathrm{di}$ alysis dementia. Semin Nephrol 2002;22: 407-414.

28 Speeckaert MM, Glorieux GL, Vanholder R, Van Biesen W, Taes YE, Clement F, Wehlou C, Delanghe JR: Vitamin D binding protein and the need for vitamin $\mathrm{D}$ in hemodialysis patients. J Ren Nutr 2008;18:400-407. 